\title{
Dry matter and grain production of two Brazilian bean genotypes in response to phosphorus nutrition"
}

\author{
R.B. Mambrin ${ }^{1}$, G.B.P. da Silva ${ }^{2}$, D. Sausen ${ }^{3}$, I.R. Carvalho ${ }^{4}$, \\ V.J. Szareski ${ }^{4}$ and G.G. Conte ${ }^{4}$ \\ ${ }^{1}$ Instituto de Desenvolvimento Educacional do Alto Uruguai, RS, Brasil \\ ${ }^{2}$ Universidade Federal do Rio Grande do Sul, Porto Alegre, RS, Brasil \\ ${ }^{3}$ Universidade Federal do Rio Grande do Norte, RN, Brasil \\ ${ }^{4}$ Universidade Federal de Pelotas, Capão do Leão, RS, Brasil
}

Corresponding author: I.R. Carvalho

E-mail: carvalho.irc@gmail.com

Genet. Mol. Res. 18 (4): gmr18053

Received June 14, 2018

Accepted November 07, 2019

Published January 31, 2019

DOI http://dx.doi.org/10.4238/gmr18053

\begin{abstract}
The amount of absorbed phosphorus directly impacts on the growth and grain yield of common bean plants. We evaluated dry matter production at different growth stages and grain yield of common bean genotypes in response to phosphorus availability in a nutrient solution and examined possible associations between these characters. The experiment was carried out in a greenhouse, using a completely randomized design in sub-sub-divided plots. The main plots consisted of five phosphorus concentrations $\left(0.5 ; 0.9 ; 1.3 ; 1.9\right.$ and $\left.2.3 \mathrm{mmol}^{-\mathrm{L}^{-1}}\right)$ supplied to plants in a nutrient solution in the growth medium. The subplots were composed of two common bean genotypes (Pérola and IPR88 Uirapurú, which are commonly used in Rio Grande do Sul state) and the sub-sub-plots by two growing seasons (fall-winter and spring-summer). In the initial stages, at the first trifoliate leaf and flowering stages, the highest dry mass production occurred in the leaves. As the plants developed, they produced more dry matter in the pods during the pod filling stage, and later in grains, at the maturation stage. Phosphorus concentrations in the nutrient solution between 1.33 and 1.84 mmol. $\mathrm{L}^{-1}$ provided the greatest mass of beans at podfilling and at maturation, the largest number of grains and the greatest grain yield in the two genotypes. The characters dry mass of the leaves, stems and pods in pod
\end{abstract}


filling, dry mass of grains at maturity, number of grains and number of pods are promising for indirect selection criteria.

Key words: Phaseolus vulgaris; Nutrient solution; Growth; Pearson correlation

\section{INTRODUCTION}

Brazil is highly dependent on fertilizer imports, especially phosphorus, with a volume of 1,4 million tons imported, corresponding to $75 \%$ of the necessities for agriculture (Lana, 2015). Due to high soil acidity, low mineral availability and mobility, high doses of phosphorus fertilizers are normally used.

Phosphorus reserves are finite and will be sufficient for 40 to 100 years at most, according to projections by Cordell et al. (2009). Therefore, efficient exploitation of this natural reserve is fundamental to increase or even maintain crop production. Also, in acid soils, part of the available phosphorus can be fixed, forming iron and aluminum components, and phosphorus precipitation or adsorption reactions can occur, making it unavailable to plants (Turuko and Mohammed, 2014).

In bean (Phaseolus vulgaris) cultivation, grain productivity is limited in Brazilian soils by the low availability of phosphorus to plants (Zucareli et al., 2011; Carvalho et al., 2018). Insufficient amounts of this element can affect crop nutrition and reduce productivity (Hernandez and Domingues, 2012).

The phosphorus doses used in bean crops depend on the soil free mineral content, on the cultivar and on the expectation of grain productivity. Although, normally, higher doses than the necessary are used (Silveira and Moreira, 1990), it is estimated that only 5 to $25 \%$ of soluble phosphorus added to soil through fertilizing are used by the crops, which means that from 75 to 95\% of added phosphorus is fixed in the soil.

The common bean is considered a highly exigent crop in terms of its requirements for nutrients. There is a direct relationship between absorbed phosphorus by bean crops and plant growth and grain production. Limitations in phosphorus availability at the beginning of the crop vegetative cycle result in restrictions in development from which the plant will not recover. This is because phosphorus is essential to plant metabolism, performing an important role in cell energy transfer, and in cell respiration and photosynthesis cycles (Cordell et al., 2009). Bean crops that are adequately fertilized with phosphorus are more resistant to environmental adversities after sowing and and can produce more seeds with better quality (Zucareli et al., 2011; Szareski et al., 2018).

Soil is constituted of a very complex and interactive environment, which makes effective analysis of a given nutrient difficult. Zucareli et al. (2011), studying the productivity and seeds quality of carioca beans under the influence of phosphorus fertilization in the soil, found great variation in results in a comparison of studies by various researchers. They concluded that response to fertilization on field depends on many factors, especially phosphorus availability in the soil, the availability of other nutrients, the cultivar evaluated and climatic conditions.

For this reason, research conducted under controlled conditions, with a nutrient solution, are of extreme importance, with special attention to avoiding toxic effects due to excess nutrients and interference of other elements found in the soil. The use of nutrient solutions allows better control of the proportions of nutrients, making it possible to cultivate plants under highly controlled conditions, including nutrient and water availability, $\mathrm{pH}$ and salinity. Also, it allows isolation of the effect of variations of other nutrients on crop growth and grain production (Snapp and Lynch; 1995). 
Most research conducted under controlled conditions, growing bean crops in nutrient solution, were developed to characterize genotypes for their efficiency in the use of phosphorus (Hernandez et al., 2007; Araújo et al., 2008). Some researchers, such as Araújo et al. (2013), studied the effect of phosphorus on dry matter production in bean crops by evaluating the interaction between phosphite and phosphate in nutrient solution. However, there are few studies under controlled conditions using nutrient solution that allow measuring the influence of phosphorus availability on plant growth and grain production. Growth analysis can be used to understand a plants ecological adaptation to new environments, to interspecific competition, to management systems and to environmental interactions (Zucareli et al., 2010).

However, much of this research was made on plants up to 30 days of development (Snapp and Lynch, 1995; Araújo, et al., 2008; Tawaraya et al., 2014). In order to nourish the plant adequately, it is necessary to understand the relationship between nutrients and plant's reaction to phosphorus that is made available throughout the growing season. It is necessary that the plant complete its cycle and that studies and analysis be made of the different growing stages.

Consequently, we evaluated dry mass production and productivity in bean cultivars at different phenological stages in response to phosphorus availability in a nutrient solution.

\section{MATERIAL AND METHODS}

The experiments were conducted in a greenhouse of the Phytotechnical Department of the Federal University of Santa Maria, in the municipality of Santa Maria, Rio Grande do Sul State, Brazil (latitude $29^{\circ} 42^{\prime} \mathrm{S}$, longitude $53^{\circ} 49^{\prime} \mathrm{W}$ and $95 \mathrm{~m}$ altitude). The plants were grown in five closed devices, as described by Domingues et al. (2014). In every device, 48 polypropylene pots with $4 \mathrm{~L}$ capacity, of black color and perforated in the base were uniformly distributed. The containers were filled with a layer of gravel $(5 \mathrm{~cm})$ and with medium sand (granulometry from 1.2 to $2.4 \mathrm{~mm}$ ), previously washed with sodium hypochlorite solution at $1 \%$. The spacing between the containers was $5 \mathrm{~cm}$ in the row and $10 \mathrm{~cm}$ between rows. Four common bean seeds were sown in each pot, and at the open leaves stage (V2) they were thinned to two plants per container.

For the analysis, we used a completely randomized design with plots sub-sub-divided into strips, with three repetitions. The main plots were constituted of five phosphorus concentrations provided to the plants through fertigation $\left(0.5 ; 0.9 ; 1.3 ; 1.9\right.$ and $\left.2.3 \mathrm{mmol} . \mathrm{L}^{-1}\right)$. The sub-plots were composed of two bean genotypes, Pérola and IPR88 Uirapurú, being chosen because they are different types of beans, and both are widely cultivated in the region. The Pérola cultivar is a carioca type, with presents vigorous growth, adaptation to numerous production systems and a medium maturation cycle of 86 days. Cultivar IPR Uirapurú is a black type, has high grain productivity potential, erect, with tolerance to water stress and high temperatures during the reproductive phase; it is relatively efficient in phosphorus usage under low phosphorus availability conditions. The sub-sub plots had two growing seasons, fall-winter (sowing March 28, 2013) and spring-summer (sowing September 2, 2013).

Fertigation was made with a nutrient solution that contained the same essential mineral nutrients in amounts adequate for plant growth and development: potassium $\left(\mathrm{KNO}_{3} ; 404.40\right.$ mg.L $\left.{ }^{-1}\right)$, calcium $\left(\mathrm{Ca}\left(\mathrm{NO}_{3}\right)_{2} ; 318.74 \mathrm{mg} . \mathrm{L}^{-1}\right)$, magnesium $\left(\mathrm{MgSO}_{4} ; 197.12 \mathrm{mg} . \mathrm{L}^{-1}\right)$, and micronutrients: molybdenum $\left(\mathrm{Na}_{2} \mathrm{MoO}_{4} ; 0.03 \mathrm{mg} . \mathrm{L}^{-1}\right)$, barium $\left(\mathrm{H}_{3} \mathrm{BO}_{3} ; 0.26 \mathrm{mg} . \mathrm{L}^{-1}\right)$, cooper $\left(\mathrm{CuSO}_{4} ; 0.06 \mathrm{mg} . \mathrm{L}^{-1}\right)$, manganese $\left(\mathrm{MnSO}_{4} ; 0.50 \mathrm{mg} . \mathrm{L}^{-1}\right)$, zinc $\left(\mathrm{ZnSO}_{4} ; 0.22 \mathrm{mg} . \mathrm{L}^{-1}\right)$, and iron $\left(\mathrm{Fe}\left(\mathrm{NO}_{3}\right)_{3} ; 1,0 \mathrm{mg} . \mathrm{L}^{-1}\right)$. Only phosphorus concentration was variable, being $0.5,0.9,1.3,1.9$, or 2.3 mmol. $\mathrm{L}^{-1} \mathrm{r}$ of $\mathrm{NH}_{4} \mathrm{H}_{2} \mathrm{PO}_{4}$. These concentrations values above and below values considered ideal for this crop, corresponding to $10.31,18.54,26.78,39.14$ and $44.38 \mathrm{Kg}^{-1}{ }^{-1}$. As the 
phosphorus source also contains nitrogen, the amount of nitrogen $\left(\mathrm{NH}_{4} \mathrm{NO}_{3}\right)$ was reduced, being: $80 \mathrm{mg} . \mathrm{L}^{-1}, 64 \mathrm{mg} . \mathrm{L}^{-1}, 48.4 \mathrm{mg} . \mathrm{L}^{-1}, 24 \mathrm{mg} . \mathrm{L}^{-1}$ and $8 \mathrm{mg} . \mathrm{L}^{-1}$.

Fertigation was supplied through drip hoses in a closed circuit. The excedent nutrient solution was drained through the device channels, which were filled with medium basaltic gravel, and returned to a $245 \mathrm{~L}$ fiberglass reservoir, which was installed at ground level, outside the greenhouse. Each solution reservoir was connected to an electric pump controlled by a timer. The solutions were in three daily shifts of fertigation during fall-winter, and five shifts during spring-summer, each with 15 min duration.

The nutrient solution $\mathrm{pH}$ was kept at 5.5 to 6.5 , through the addition of $\mathrm{NaOH}$ or $\mathrm{H}_{2} \mathrm{SO}_{4}$ at $1 \mathrm{~N}$ concentration. When the electric conductivity (CE) presented a diversion superior to $10 \%$ in relation to its initial value (varying from 1.0 to $1.5 \mathrm{mS}$ ), a correction was realized with addition of water or new nutrient solution. The $\mathrm{pH}$ and electric conductivity quantification of the solutions contained in the reservoirs was run three times a week. The nutrient solution were completely renewed in the reservoirs every 15 days.

Three plants of each cultivar were harvested at the development stages of third trifoliate leaf, flowering (R6) and pod filling (R8), characterized according to the phonological scale described by Fernandez et al. (1982), to determine the dry matter. After harvesting, each plant was divided into leaves and stems, and at the R8 stage, as well the pods. The plant tissues were kept individually in paper envelelopes and taken to a kiln (brand SPLabor, model SP-102/603, São Carlos, SP, Brazil), with forced air circulation $\left(65\right.$ to $\left.70^{\circ} \mathrm{C}\right)$ until constant mass, when the $\%$ leaves, stem and pods were determined (grams/plant). At the maturation stage (R9), quantification was made of the number of pods per plant, number of grains per plant and grain production in grams per plant, at $13 \%$ humidity. Also at the R9 stage, grain dry matter (grams/plant) was measured.

The data were submitted to variance analysis, considering all the effects as fixed except for the error, which was considered random. As the effect of the triple interaction was significant, it was unfolded in three double interactions. For this, the complementary analysis test of the factor in the main plot (phosphorus concentration in the nutrient solution) was used, within each level of the factor that is in the subplot (genotypes) and sub-subplot (times). When the interactions were significant, regression analysis was performed for the phosphorus concentrations, adjusting the equation of higher degree, and the $\mathrm{F}$ test, with a 5\% probability considered significant for comparing means between genotypes or growing seasons.

The associations between characters were obtained from the phenotypic matrix estimative with the Pearson linear correlation coefficients among the 11 evaluated characteristics (dry matter and production characteristics). The significance of the coefficients with the $t$ Student test at $5 \%$ probability. The statistical analyses were made using Microsoft ${ }^{\circledR}$ Office Excel and the softwares Sisvar (Ferreira, 2011), Genes (Cruz, 2013) and Sigma Plot (Sigmaplot, 2008).

\section{RESULTS AND DISCUSSION}

In the variance analysis, a significant triple interaction was observed (phosphorus concentration $\mathrm{x}$ genotype $\mathrm{x}$ growing season: $\mathrm{C} \mathrm{x} \mathrm{G} \times \mathrm{E}$ ) for the characters dry matter of: leaves at V3, leaves at R6, stem at R8 and grains at R9; and for grain production. It indicates that, for these characters, at different phosphorus concentrations provided by fertigation, the genotypes varied in relation to the growing seasons. According to Kikuti et al. (2007), studying the effect of nitrogen and phosphorus fertilization effect on grains productivity in common bean cultivars, during two growing seasons, also found a significant triple interaction $\mathrm{C} \times \mathrm{G} \times \mathrm{E}$ affecting grain production. 
For the characters stem dry mass at V4, pods at R8 and grain number at R9, there was a significant interaction of phosphorus concentration $\mathrm{x}$ genotype $(\mathrm{C} \times \mathrm{G})$ interaction. This interaction demonstrates that phosphorus concentration affects the bean genotypes differently. Evaluating the efficiency of the phosphorus use in common beans genotypes in nutrient solutions, Hernandez et al. (2014) found a significant C x G interaction on stem dry mass. Lana et al. (2006) evaluated eight common bean genotypes for efficiency in phosphorus absorption and utilization, when cultivated in two phosphorus concentration in nutrient solution, and also found significant $\mathrm{C} \times \mathrm{G}$ interactions affecting shoot dry mass production.

In relation to the significance of the interaction phosphorus concentration $\mathrm{x}$ growing season ( $\mathrm{C} \times \mathrm{E}$ ), which was observed to the characters dry matter: of leaves in V4, R6 and R8; of stem in R6 and R8; of pods in R8 and grains in R9. Besides the pods and grains number in R9 and grains productivity. Consequently, it was evidenced that the environmental conditions at the growing season, specially the temperature, exerted influence on how the bean plants absorbed the phosphorus in the solution and thus, reflected on the plants growth and production. Since the principal transport mechanism of phosphorus on the soil is the diffusion, which is influenced by the phosphorus-colloid interaction, by the element content and air temperature (Costa et al., 2006), it is understood that the conditions during the productive period indirectly acted on the dry mass accumulation and productivity of common bean plants. It is justified by the fact that low temperatures can influence the plant in the phosphorus obtainment, mostly in the initial growth stages, due to the slower diffusion in these conditions, and having lower phosphorus solubility in the soil (Grant et al., 2001).

For the characters leaves and pods in R8 dry matter and grains in R9 number, there was no triple interaction $\mathrm{C} \times \mathrm{G} \times \mathrm{E}$, however, it was verified the significant interaction genotype $\mathrm{x}$ growing season $(\mathrm{G} \times \mathrm{E})$, characterizing a differentiate effect on the common bean genotypes in relation to the growing season variation. The evaluation of the interaction is important to plants breeding, due to the possibility of a line to develop well in a given environment, and at other do no present favorable characters, making possible to indicate lines to specifics growing seasons (Faria et al., 2009).

We obtained a linear response for the cultivar Perola, in relation to the phosphorus concentration provided in the fertigation, in the characters leaves in V4 (Figure 1A) and R6 (Figure 1C) dry matter, and for the cultivar IPR88 Uirapurú in the characters stem in V4 (Figure 1B) and R8 (Figure 1D) dry matter. In this manner, the phosphorus concentration of 2.3mmol.L ${ }^{1}$ proportionate larger leaves and greater stem growth of the common bean plants. These results are similar to those found by Leal and Prado (2008), in research with nutrient solution to evaluate the nutritional disorders in beans due to phosphorus deficiency. They found that the phosphorus supply proportionated greater vegetative growth in the plants, causing a linear increase in the leaves and stem dry matter production. Also, for the cultivar IPR88 Uirapurú on the characters leaves in V4 (Figure 1A) and R6 (Figure 1C) dry matter, and the cultivar Perola on the characters stem in V4 (Figure 1B) and R8 (Figure 1D) dry matter, there was a quadratic response, with point of maximum efficiency estimated in the phosphorus concentrations of 1.6; $1.8 ; 1.3$ and 1.5 mmol. $\mathrm{L}^{-1}$, respectively.

Both bean cultivars presented quadratic results for the characters pods dry matter at R8 (Figure 1E), grain number at R9 (Figure 1F), grain number at R9 (Figure 1G) and grain productivity (Figure 1H). As the point of maximum technical efficiency for these characters occurred at the following phosphorus concentrations: $1.33 \mathrm{mmol} . \mathrm{L}^{-1}$ - Pérola and $1.56 \mathrm{mmol} . \mathrm{L}^{-1}$ - IPR88 Uirapurú (Figure 1E), $1.67 \mathrm{mmol} . \mathrm{L}^{-1}$ - Pérola and $1.45 \mathrm{mmol} . \mathrm{L}^{-1}$ - IPR88 Uirapurú (Figure 1F), 1.53 mmol.L ${ }^{-1}$ - Pérola and $1.74 \mathrm{mmol}^{-1} \mathrm{~L}^{-1}$ IPR88 Uirapurú (Figure 1G), 1.54 mmol. $\mathrm{L}^{-1}$ - Pérola and $1.56 \mathrm{mmol.L^{-1 }}$ - IPR88 Uirapurú (Figure 1H), it is evident that there is 
genetic variability among these cultivars. Therefore, inferior phosphorus concentrations and/or superior than these values, do not granted adequate nutrient supply to the bean plants growth. According to Fageria (2003), the phosphorus influence in the common bean crop resides in the increase of dry matter production of pods and grains, besides the pods number, that are the grain productivity principal determinant. That happens because the phosphorus is the energetic constituent of plants and, in this way, favors biosynthesis processes (Fontes, 2016).
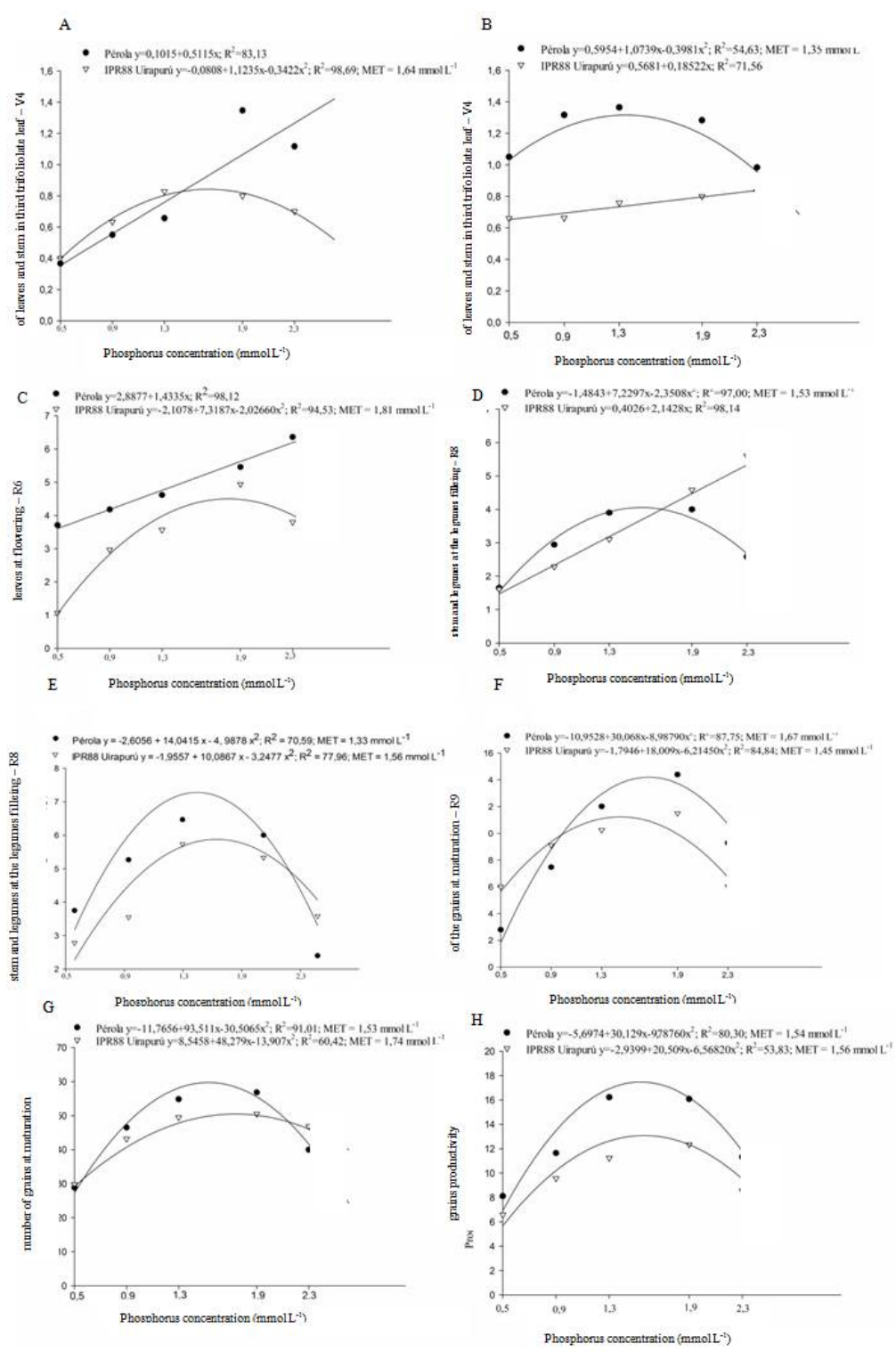

Figure 1. Dry matter of leaves and stems at the third trifoliolate leaf stage - V4 (A) and (B); leaves at flowering R6 (C); stem and pods at the pods filling stage- R8 (D) e (E); of the grains at - R9 (F); number of grains at maturation $(\mathrm{G})$ and grain production $(\mathrm{H})$, obtained in five phosphorus concentrations in the nutrient solution to the cultivation of two common bean genotypes (Pérola and IPR88 Uirapurú). 
At the fall-winter growing season (season 1) for the characters dry matter of leaves at V4, R6 and R8 (Figure 2A, 2B, and 2D) and of stem at R6 and R8 (Figure 2C and 2E), the common beans genotypes gave a quadratic result as a function of the phosphorus concentration provided by fertigation. For the characters dry matter of leaves at R6 and stem at R6, in the growing season 2 (Figure $2 \mathrm{~B}$ and $2 \mathrm{C}$ ), there was no linear result, quadratic or cubic, consequently, the values were not included.
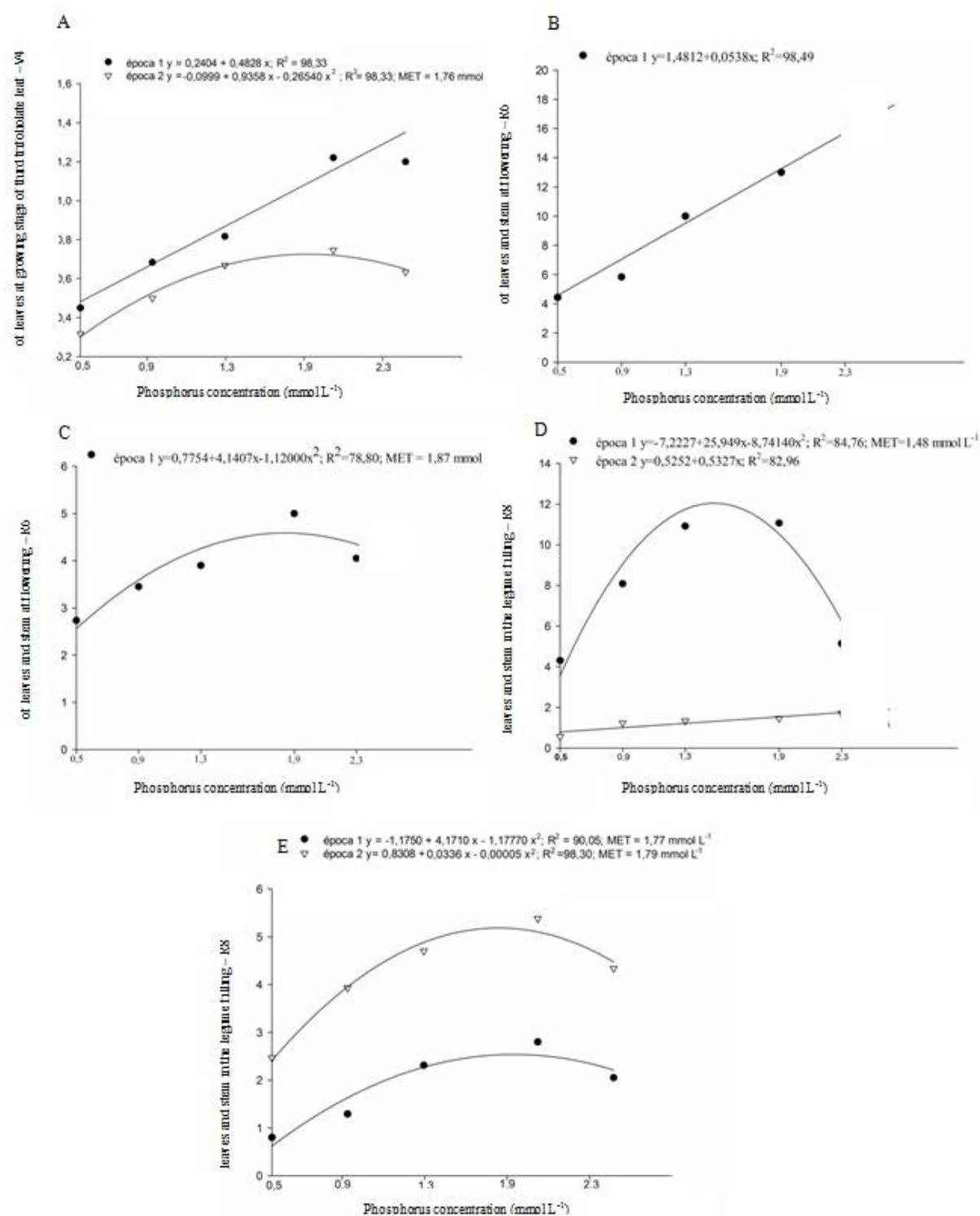

Figure 2. Dry matter of leaves at the third trifoliolate leaf growth stage - V4 (A), of leaves and stem at flowering - R6 (B) and (C), and leaves and stem at the pod filling stage - R8 (D) and (E), of common bean genotypes cultivated with five phosphorus concentrations in the nutrient solution, in the growing seasons of fall-winter (season 1) and spring-summer (season 2) in Santa Maria, RS. 
At the phonological growth stages of pods filling and maturation, for the character of pods at R8 dry matter (Figure 3A) and the grains at R9 (Figure 3B), pods at R9 number (Figure $3 \mathrm{C}$ ), grain number at $\mathrm{R} 9$ (Figure 3D) and grain productivity (Figure 3E), the common beans behavior can be expressed by a second degree equation, in both growing seasons (seasons 1 and 2). Besides that, to these characters, the maximum technic efficiency point happened in the following phosphorus concentrations: $1.42 \mathrm{mmol} . \mathrm{L}^{-1}$ - season 1 and $1.52 \mathrm{mmol} . \mathrm{L}^{-1}$ - season 2 (Figure 3A), $1.55 \mathrm{mmol} . \mathrm{L}^{-1}$ - season 1 and $1.67 \mathrm{mmol.L}{ }^{-1}$ - season 2 (Figure 3B), $1.52 \mathrm{mmol.L^{-1 }}$ season 1 and $1.84 \mathrm{mmol} . \mathrm{L}^{-1}$ - season 2 (Figure 3C), $1.52 \mathrm{mmol} . \mathrm{L}^{-1}$ - season 1 and $1.58 \mathrm{mmol} . \mathrm{L}^{-1}$ season 2 (Figure 3D) and 1.49 mmol. $\mathrm{L}^{-1}$ - season 1 and $1.76 \mathrm{mmol} . \mathrm{L}^{-1}$ - season 2 (Figure 3E). This behavior can be justified due the phosphorus being applied in the location, thru the fertigation. In this manner, the nutrient was made available to the bean crops radicular system, even though it was in lower amounts, collaborating to the increase of shoot, pod and grains dry matter.
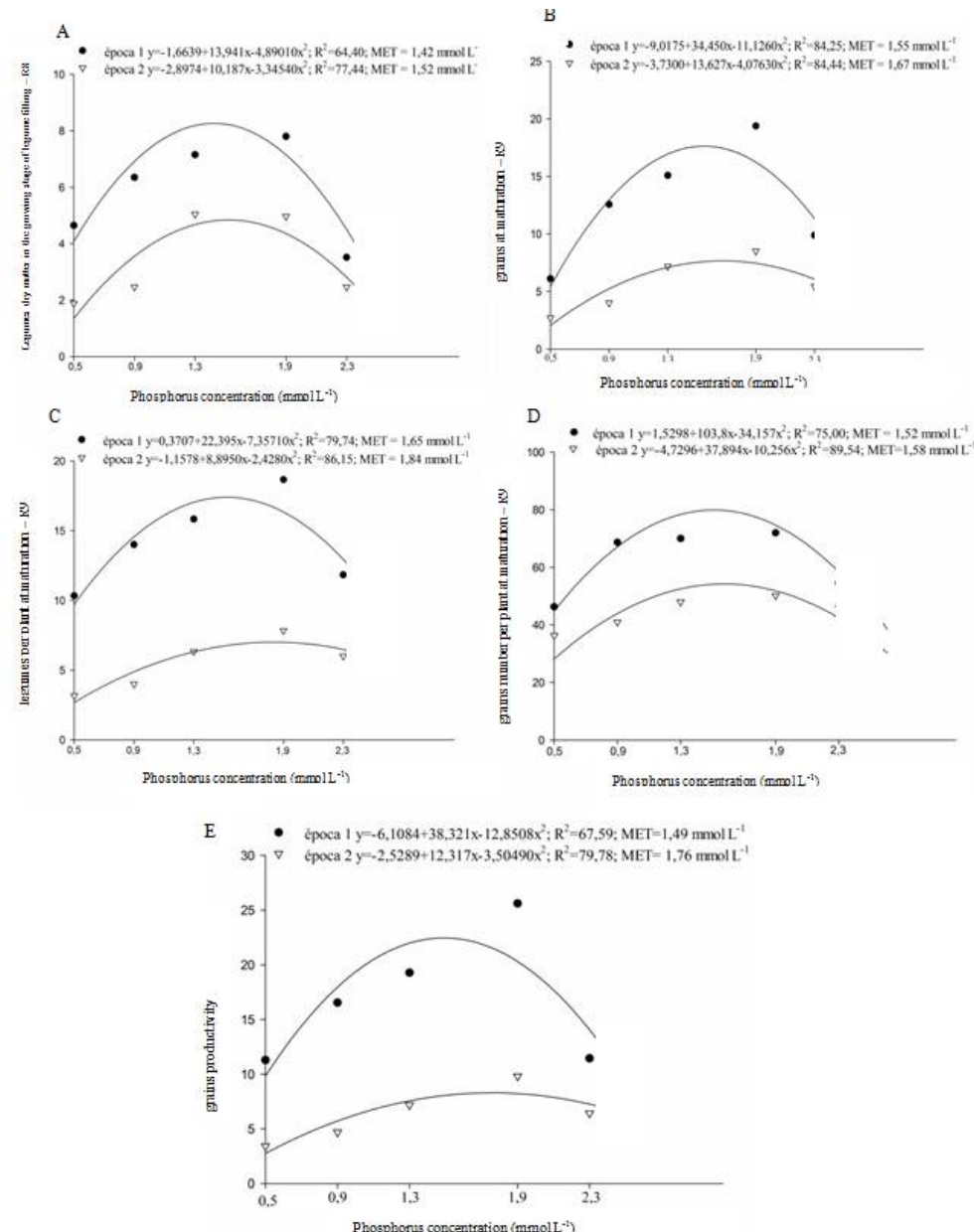

Figure 3. Pod dry matter at the growing stage of pod filling - R8 (A) and grains at maturation - R9 (B), pods per plant at maturation - R9 (C), grain number per plant at maturation - R9 (D) and grain productivity (E), obtained with five phosphorus concentrations in the nutrient solutions, in the growing seasons of fall-winter (season 1) and spring - summer (season 2). 
There has been little research on the influence of phosphorus concentration, available in the nutrient solution, on dry mass and grain production in common bean plants. Although, under field conditions, Fernandes et al. (2013), analyzing caupi beans, in relation to the phosphate fertilizing in the soul, as in this research, found a quadratic result for pod and grain dry matter. Similarly, Silva and Vahl (2002), researching different phosphorus doses in soil, obtained a quadratic result for grain productivity, considering the cultivars BR FEPRAGRO 44 and Guapo Brilhante.

The fall-winter (season 1) was favorable for growth and production of the cultivar Pérola, which differed from cultivar IPR88 Uirapuru for all characters, forming the group with the highest averages (Table 1). On the other hand, in the spring-summer crop (season 2), the cultivar IPR88 Uirapurú constituted the group with the higher averages for the characters leaves at V4, R6 and R8 dry matter, and grains number at R9, differing from the cultivar Pérola. This divergence of results behavior, in relation to the leaves dry matter accumulation is similar to what was found by Souza and Lobato (2006), who affirmed that the response to phosphate fertilization in bean crops depends on several factors, highlighting abiotic conditions, such as air temperature and solar radiation.

Table 1. Mean values obtained for the dry matter characters: of leaves at third trifoliolate leaf - V4 (DM Leaf V4, g), of leaves at flowering - R6 (DM Leaf R6, g), of stem at flowering - R6 (DM Stem R6, g), of leaves at pod filling - R8 (DM Leaf R8, g), of stem at pod filling - R8 (DM Stem R8, g), of pods at pod filling - R8 (MSV R8, g), of grains at maturation - R9 (MSG R9, g); grain number at maturation - R9 $\left(\mathrm{N}^{\circ} \mathrm{G}\right.$ R9) and grain productivity (Prod, g.planta ${ }^{-1}$ ), obtained for two bean genotypes (Pérola and IPR88 Uirapurú), cultivated under different concentrations of phosphorus in the nutrient solution, in the fallwinter (season 1) and spring-summer (season 2).

\begin{tabular}{|c|c|c|c|c|c|c|c|c|c|c|c|c|c|c|c|c|c|c|c|c|}
\hline \multirow{4}{*}{$\begin{array}{l}\text { Genotype } \\
\text { Pérola } \\
\text { IPR88 Uirapurú }\end{array}$} & \multicolumn{4}{|c|}{ DM Leaf V4 } & \multicolumn{4}{|c|}{ DM Leaf R6 } & \multicolumn{4}{|c|}{ DM Stem R6 } & \multicolumn{4}{|c|}{ DM Leaf R8 } & \multicolumn{4}{|c|}{ DM Stem R8 } \\
\hline & \multicolumn{2}{|c|}{ season 1} & \multicolumn{2}{|c|}{ season 2} & \multicolumn{2}{|c|}{ season 1} & \multicolumn{2}{|c|}{ season 2} & \multicolumn{2}{|c|}{ season 1} & \multicolumn{2}{|c|}{ season 2} & \multicolumn{2}{|c|}{ season 1} & \multicolumn{2}{|c|}{ season 2} & \multicolumn{2}{|c|}{ season 1} & \multicolumn{2}{|c|}{ season 2} \\
\hline & 1.13 & $\mathrm{a}$ & 0.48 & $\mathrm{~b}$ & 9.09 & $\mathrm{a}$ & 0.64 & $\mathrm{~b}$ & 3.61 & $\mathrm{a}$ & 4.38 & $\mathrm{a}$ & 9.56 & $\mathrm{a}$ & 1.05 & $\mathrm{~b}$ & 2.14 & $\mathrm{a}$ & 4.47 & $\mathrm{a}$ \\
\hline & 0.68 & $\mathrm{~b}$ & 0.67 & $\mathrm{a}$ & 5.39 & $\mathrm{~b}$ & 1.51 & $\mathrm{a}$ & 4.15 & $\mathrm{a}$ & 2.77 & $\mathrm{~b}$ & 6.88 & $\mathrm{~b}$ & 1.47 & $\mathrm{a}$ & 1.56 & $\mathrm{~b}$ & 4.58 & $\mathrm{a}$ \\
\hline \multirow[t]{2}{*}{ Mean } & 0.91 & & 0.57 & & 7.24 & & 1.08 & & 3.88 & & 3.57 & & 8.22 & & 1.26 & & 1.85 & & 4.52 & \\
\hline & \multicolumn{4}{|c|}{ MS Vagem R8 } & \multicolumn{4}{|c|}{ DM Grain R9 } & \multicolumn{4}{|c|}{$\mathbf{N}^{\circ}$ GR9 } & \multicolumn{4}{|l|}{ Prod } & & & & \\
\hline Genotype & \multicolumn{2}{|c|}{ season 1} & \multicolumn{2}{|c|}{ season 2} & \multicolumn{2}{|c|}{ season 1} & \multicolumn{2}{|c|}{ season 2} & \multicolumn{2}{|c|}{ season 1} & \multicolumn{2}{|c|}{ season 2} & \multicolumn{2}{|c|}{ season 1} & seaso & 2 & & & & \\
\hline Pérola & 6.77 & $\mathrm{a}$ & 3.53 & $\mathrm{a}$ & 13.94 & $\mathrm{a}$ & 5.24 & $\mathrm{a}$ & 71.87 & $\mathrm{a}$ & 20.53 & b & 19.89 & $\mathrm{a}$ & 6.27 & $\mathrm{a}$ & & & & \\
\hline IPR88 Uirapurú & 5.59 & $\mathrm{~b}$ & 3.21 & $\mathrm{a}$ & 11.26 & $\mathrm{~b}$ & 5.89 & $\mathrm{a}$ & 58.73 & $\mathrm{~b}$ & 26.80 & $\mathrm{a}$ & 13.78 & $\mathrm{~b}$ & 6.34 & $\mathrm{a}$ & & & & \\
\hline Mean & 6.18 & & 3.37 & & 12.60 & & 5.57 & & 65.30 & & 23.67 & & 16.83 & & 6.30 & & & & & \\
\hline
\end{tabular}

When considering more than one environment, besides the ambient and genetic effects, the effect caused by the genotype x environment interaction stands out as well (Cruz et al, 2014). The interaction is influenced by different factors, among them the technological level stands out, as well the year's variation, locations and sowing season. In a competition experiment with common bean cultivars, conducted in Goias by Pereira et al. (2010), it was verified that the genotype $\mathrm{x}$ gorwing season and genotype $\mathrm{x}$ year $(\mathrm{G} x \mathrm{Y})$ interactions were more expressive. In this manner, it is up to the breeder to evaluate the magnitude and significance of the $\mathrm{G} \times \mathrm{A}$ interaction thru the lines evaluation in multiple environments, allowing its indication to specific and/or general environments.

It is noticeable an inversion in the genotypes behavior, with the change in the growing environment, what is explained by the differences between air medium temperature and solar radiation, that were registered in the two growing seasons (Figure 4). In the fall- 
winter cultivation, the May and July mean temperatures were below the ideal to the culture development, which varies from 17.5 to $24^{\circ} \mathrm{C}$ (Valderrama et al., 2009). This fact could have benefited the plants growth and production of the Pérola cultivar. It happens because the dry matter and carbohydrates accumulation in the diverse parts of the common bean plants is influenced by the growth habit (Kikuti et al., 2007). As the Pérola cultivar is a type III plant, with indeterminate habit, prostrated or semiprostrated, with open and welldeveloped ramification, it is characterized by continuing emitting vegetative leaves and branches after the flowering beginning (Dourado Neto et al., 2009). Therefore, in adversity conditions, presents vantages by keep growing, even in low levels in environmental resources (Radosevich, 2007), where this can be an indicative of the most well adapted cultivar. The stability and adaptability estimate of bean genotypes propitiate a higher security indication. The cultivars identification, with higher phenotypic stability, have been a very well used alternative in order to attenuate the genotype interactions effect with environments and making the cultivar indication process safer (Melo et al., 2007).

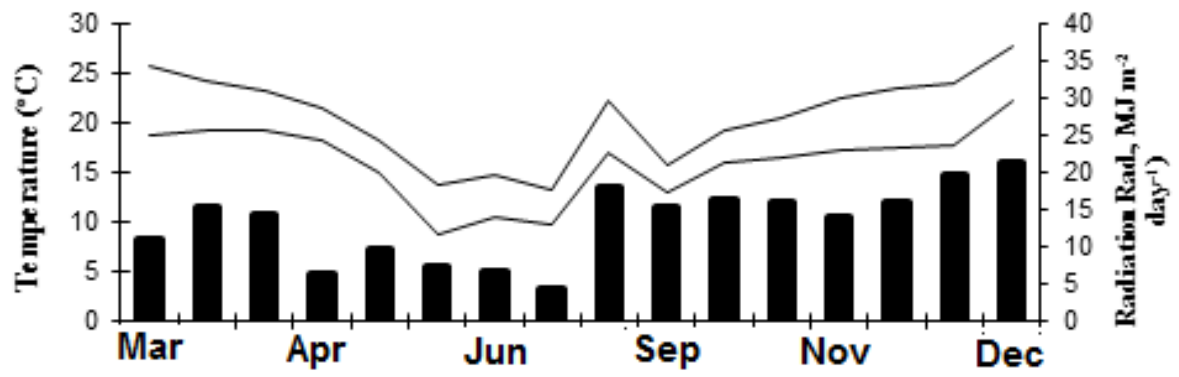

Figure 4. Fortnight values of the minimum temperature $\left({ }^{\circ} \mathrm{C}\right)$, maximum temperature $\left({ }^{\circ} \mathrm{C}\right)$ and radiation $(\operatorname{Rad} ., \mathrm{MJ}$ $\mathrm{m}^{-2}$ day $^{-1}$ ) in the crop seasons of fall-winter of 2013 (season 1) and spring-summer of 2013 (season 2). Meteorological data collected at the 8th District of Meteorology, in the Santa Maria Meteorological Station. Santa Maria - RS, UFSM.

In the spring-summer cultivation (season 2) the cultivar IPR88 Uirapurú stands out due to the proximity of solar radiation to the ideal values to development and production of common beans than in the season 1, with 15 and $22 \mathrm{MJ} \mathrm{m}^{-2} \mathrm{dia}^{-1}$ (Paula Júnior et al., 2004). Since it is a crop with determined growth habit, shrubby, erectus and branched stem, that normally flowers and matures in less time, being precocious, what makes them stay less time exposed to conditions of environmental adversity. In the fall-winter growing season, at May and June months, there was lower radiation incidence than the necessary to the bean crops. The crop interception of solar radiation and the utilization of this energy to the biomass production represents the fundamental process that governs the crops growth and grains productivity.

The Pearson correlation coefficient varied from -0.35 (stem in V4 dry matter and stem at R6 dry matter) to 0.99 (grains at R9 dry matter and pods at R9 number) (Table 2). The grains productivity presented high magnitude of correlation estimates with the characters of leaves dry matter $(r=0.96)$, stem $(r=a .96)$ and pods $(r=0.90)$ in the $R 8$ growth stage and grains dry matter $(r=0.95)$, grains number $(r=0.97)$ and pods at $\mathrm{R} 9$ dry matter $(\mathrm{r}=0.98)$. 
Table 2. Pearson correlation estimates between characters of dry matter in different growth stages: leaves at third trifoliate leaf - V4 (DM Leaf V4), stem at third trifoliolate leaf - V4 (DM Stem V4), leaves at flowering - R6 (DM Leaf R6), stem at flowering - R6 (DM Stem R6), leaves at pod filling - R8 (DM Leaf R8), stem at pod filling - R8 (DM Stem R8), pods at pod filling - R8 (DML R8), grains at maturation - R9 (DMG R9); pod number at maturation - R9 (NL R9), grain number at maturation - R9 (NG R9) and grain productivity (Prod), evaluated for five phosphorus concentrations in the nutrient solution, for two bean genotypes cultivated in two sowing seasons. Santa Maria - RS, UFSM.

\begin{tabular}{|c|c|c|c|c|c|c|c|c|c|c|c|c|c|c|c|c|c|c|c|}
\hline & DMSV4 & DMLR6 & & DM SR6 & & DMLR8 & & DMS R8 & & \begin{tabular}{|l} 
DML R8 \\
\end{tabular} & & DMG R9 & & NG9 & & NL R9 & & PROD & \\
\hline DMLV4 & 0.23 & 0.87 & ns & 0.10 & ns & 0.45 & ns & 0.55 & ns & 0.29 & ns & 0.81 & ns & 0.59 & ns & 0.75 & ns & 0.61 & $\mathrm{~ns}$ \\
\hline DMSV4 & & $-0,24$ & $\mathrm{~ns}$ & -0.35 & ns & 0.71 & $\mathrm{~ns}$ & 0.52 & ns & 0.83 & $\mathrm{~ns}$ & 0.48 & ns & 0.65 & ns & 0.59 & $\mathrm{~ns}$ & 0.63 & ns \\
\hline DMLR6 & & & & 0.36 & ns & 0.12 & ns & 0.32 & ns & 0.14 & ns & 0.57 & ns & 0.30 & ns & 0.46 & $\mathrm{~ns}$ & 0.28 & ns \\
\hline DMSR6 & & & & & & 0.33 & ns & 0.52 & ns & 0.04 & ns & 0.35 & ns & 0.38 & ns & 0.30 & $\mathrm{~ns}$ & 0.28 & ns \\
\hline DMLR8 & & & & & & & & 0.97 & ${ }^{*}$ & 0.94 & ${ }^{*}$ & 0.87 & ns & 0.98 & ${ }^{*}$ & 0.92 & ${ }^{*}$ & 0.96 & ${ }^{*}$ \\
\hline DMSR8 & & & & & & & & & & 0.82 & ns & 0.93 & * & 0.98 & * & 0.95 & * & 0.96 & $*$ \\
\hline DMLR8 & & & & & & & & & & & & 0.72 & ns & 0.87 & ns & 0.81 & ns & 0.90 & * \\
\hline DMGR9 & & & & & & & & & & & & & & 0.94 & ${ }^{*}$ & 0.99 & ${ }^{*}$ & 0.95 & * \\
\hline NG9 & & & & & & & & & & & & & & & & 0.97 & * & 0.97 & $*$ \\
\hline NLR9 & & & & & & & & & & & & & & & & & & 0.98 & $*$ \\
\hline
\end{tabular}

It was observed that the coefficient for these characters had a positive linear association, indicating that to have an increase in the grain productivity, the variables that affect photosynthesis must be maximized. Similar results were observed by Oliveira et al. (2013), by investigating the genotypic relations between the grains productivity in beans with the grains productivity compounds in agronomic characteristics. The authors verified that the genetic relation of high direct and positive effect of shoot dry matter and pods per plant number with the productivity. The same as Coutinho et al. (2014), studying the growth and productivity of caupi beans in response to phosphorus doses in Yellow Latosol, observed a positive correlation between grains number and pod per plant.

Although, diverging from results found in this group, Borges et al. (2012), in a research about correlation between dry matter and grains production in bean crops, verified significant and positive correlation among grains productivity and dry matter of leaves and stem at 35 days after seedlings emergence, period that correspond to the flowering stage (R6). Although, at 65 days after emergence, when the pods formation begins (R8), there was no significant interaction for these characters.

In this research, the significance of the correlation estimates was observed at $\mathrm{r} 8$ growing stage, indicating dry mass production of young plants, in the initial phonological stages, did not correlated with grains productivity. In this manner, there higher amounts of mass in the V4 and R6 stages will not reverberate in higher grains productivity. Although, the evaluation of characters of dry mass production and productivity compounds, thru R8 stage, can be promising by allowing the indirect selection, with the intent to obtain genetic gains on the grains productivity.

\section{CONCLUSIONS}

The phosphorus concentrations in the nutrient solution between 1.33 and 1.84 mmol.L-1 proportionated higher amounts of pod dry mass, grain number and grain productivity. For these characters, the genotype behavior varies due to the growing season and the phosphorus concentration in the nutrient solution. The leaves, stem and pods dry mass characters at pod filling, grain dry matter at maturation, grain number and pod number 
at maturation are promising for indirect selection, with the intent to obtain genetic gains in grain productivity. There was an inversion in the genotype behavior, with change in growing season, where the Pérola cultivar was better adapted, obtaining higher growth and production in the non-preferential growing season, the fall-winter.

\section{ACKNOWLEDGMENTS}

We thank the National Council for Scientific and Technological Development $(\mathrm{CNPq})$ and the Coordination for the Improvement of Higher Level or Education Personnel (Capes) for the scholarships granted.

\section{CONFLICTS OF INTEREST}

The authors declare no conflict of interest.

\section{REFERENCES}

Andrade CAB, Scapim CA, Lucca A and Martorelli DT (2009). Yield, growth and dry matter partition in two common bean cultivars. Acta Sci. Agron. 3: 683-688. http://dx.doi.org/ 10.4025/actasciagron.v31i4.6397.

Araújo AP, Plassard C and Drevon JJ (2008). Phosphatase and phytase activities in nodules of common bean genotypes at different levels of phosphorus supply. Plant Soil. 3: 129-138. http://dx.doi.org/10.1007/s11104-008-9595-3.

Araújo JL, Faquin V, Ávila FW and Pedroso TQ (2013). Effect of phosphite-phosphate interaction on growth and on phosphorus nutrition of commonbean in nutrient solution. Rev. Bras. Ciênc. Solo. 3: 482-490. http://dx.doi.org/10.1590/S0100-06832013000200019.

Benincasa MMP (2006). Análise de crescimento de plantas: noções básicas. Jaboticabal: FUNEP. 42 p.

Borges PRS, Rogério P, Saboya C, Cássia R, et al. (2012). Dry mass partitioning and grain yield of cowpea plants inoculated with rhizobia in gurupi, TO. Rev. Caatinga. 2: 37-44.

Carvalho IR, Szareski VJ, Demari GH, Barbosa MH, et al. (2018). Artificial Neural Network and Multivariate Models Applied to Morphological Traits and Seeds of Common Beans Genotypes. J. Agr. Sci. 10: 572-580. https://doi.org/10.5539/jas.v10n11p572.

Comissão técnica sul-brasileira de feijão. (2012). Informações técnicas para o cultivo de feijão na Região Sul brasileira. $157 \mathrm{p}$.

Cordell D, Drangert JO and White S (2009). The story of phosphorus: Global food security and food for thought. Global Environmental Change, Ontário, 1: 292-305. https://doi.org/10.1016/j.gloenvcha.2008.10.009.

Costa JPV, De Barros NF, Albuquerque AW, Filho GM, et al. (2006). Influence of phosphorus doses and soil moisture on diffusion flow. Rev. Bras. Eng. Agr. Amb. 10: 828-835. http://dx.doi.org/10.1590/S1415-43662006000400007.

Cruz CD (2013). GENES - A software package for analysis in experimental statistics and quantitative genetics. Acta Sci. Agron. 35: 271-276. https://doi: 10.4025/actasciagron.v35i3.21251.

Coutinho PWR, Da Silva DMS, Saldanha ECM, Okumura RS, et al. (2014). Rates of phosphorus fertilizers in the culture of cowpea in the northeasternon State of Pará.Rev.Agro@mbiente On-line. 8: 66-73.

Cruz CD, Carneiro PCS and Regazzi AJ (2014). Modelos biométricos aplicados ao melhoramento de plantas. 3 Ed, $585 \mathrm{p}$.

Domingues LS, Ribeiro ND, Andriolo JL, Possobom MTDF, et al. (2014). Selection of common bean lines for calcium use efficiency. Rev. Ciên. Agron. 45: 767-776. http://dx.doi.org/10.1590/S1806-66902014000400015.

Dourado-Neto D and Fancelli AL (2009). Produção de feijão, 3 Ed, 385p.

Fageria NK (2003). Optimizing nutrient use efficiency in crop production. Rev. Bras. Eng. Agr. Amb. 2: 6-16. http://dx.doi.org/10.1590/1807-1929/agriambi.v02n01p6-16.

Faria AP, Cirino MV, Buratto JS, Da Silva CFB, et al. (2009). Genotype x environment interaction in the grain yield of lines and cultivars in common bean. Acta Scientiarum Agronomy. 3: 579-585. http://dx.doi.org/10.1590/S180786212009000400005 .

Fernandes AR, Fonseca MR and Braz AMS (2013). Produtividade de feijão caupi em função da calagem e fósforo. Rev. Caatinga. 2: 54-62.

Fernandez F, Gepts P and Lopes M (1982). Etapas de desarollo de la planta de frijol comum. Cali: Centro Nacional de Agricultura Tropical. 2: 508. http://ciat-library.ciat.cgiar.org/ciat_digital/CIAT/28093.pdf- 519 .

Ferreira DF (2011). Sisvar: a computer statiscal analysis system. Ciênc. Agrotech. 3: 1039-1042. http://www.scielo.br/scielo.php?script=sci_arttext\&pid=S1413-70542011000600001. 
Grant CA (2001). A importância do fósforo no desenvolvimento inicial da planta. Informações Agronômicas. 9: 1-16. www.ipni.net/publication/ia-brasil.nsf/0/.../\%24FILE/Jornal\%2095.pdf.

Hernandez G, Ramíres E, Lópes OV, Tesfaye M, et al. (2007). Phosphorus stress in common bean: Root transcript and metabolic responses. Plant Physiol. 14: 752-767. https://doi.org/10.1104/pp.107.096958.

Hernández-Domíguez EE, Valencia-Turcotte LG and Rodríguez-Sotres R (2014). Changes in expression of soluble inorganic pyrophosphatases of Phaseolus vulgaris under phosphate starvation. Plant Sci. 1: 39-48. https://www.ncbi.nlm.nih.gov/pubmed/22404831.

Kikuti H, Andrade MJB, Carvalho JG and Morais AR (2007). Nitrogen and phosphorus in the cultivated variety bean BRS MG Talismã (Phaseolus vulgaris L.). Acta Sci. Agron. 2: 415-422. http://www.scielo.br/scielo.php?script=sci_arttext\&pid=S0100-69162014000500012].

Lana RMQ, Júnior LAZ, Correia NM and Lana AMQ (2006). Variabilidade entre genótipos de feijoeiro na eficiência no

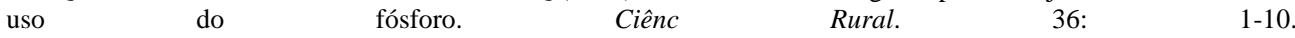
http://www.scielo.br/scielo.php?pid=S010384782006000300009\&script=sci_abstract\&tlng=pt].

Lana RP (2015). Respostas de animais e plantas aos nutrientes. Viçosa, 171.

Leal RM and Prado RM (2008). Desordens nutricionais no feijoeiro por deficiência de macronutrientes, boro e zinco. Rev. Bras. Ciênci Agrár $\quad 3:$ 301-306. http://www.nutricaodeplantas.agr.br/site/downloads/unesp_jaboticabal/omissao_feijao9.pdf

Melo LC, Melo PGS, Faria LS, Diaz JLC, et al. (2007). Interaction with environment and stability of common bean genotypes in the South Centre Region of Brazil. Pesq. Agropec. Bras. 42: 715-723. http://dx.doi.org/10.1590/S0100-204X2007000500015.

Oliveira AP, Araújo RS, Alves EU, Noronha MAS, et al. (2011). Yield of cowpea-beans cultivated with bovine manure and mineral fertilization. Hort. Bras. 1: 81-84. http://dx.doi.org/10.1590/S0102-05362001000100017.

Paula Júnior TJ (2004). Informe Agropecuário, 25 Ed, 223-230.

Pereira HS, Melo LC, De Faria LC, Peloso MJD, et al. (2010). Indicação de cultivares de feijoeiro-comum baseada na avaliação conjunta de diferentes épocas de semeadura. Pesq. Agropec. Bras. 45: 571-578. http://dx.doi.org/10.1590/S0100-204X2010000600006.

Radosevich AC (2007). Ecology of weeds and invasive plantas: Relation ship to agriculture and natural resource management. Hoboken: John Wiley Sons, Washington, 1: 130-147. http://www.bioone.org/doi/abs/10.3159/10-BR001.1 .

Ribeiro ND, Domingues LS, Zemolin AEM and Possobom MTDF (2013). Selection of common bean lines with high agronomic performance and high calcium and iron concentrations. Pesq. Agropec. Bras. 4: 1368-1375. http://dx.doi.org/10.1590/S0100-204X2013001000008.

Silveira PM and Moreira JAA (1990). Response of the beanto doses of phosphorus and irrigation water slides. Rev. Bras. Ciênc. Solo. 1: 63-67. http://www.scielo.br/pdf/brag/2015nahead/0006-8705-brag-1678-4499176.pdf.

Snapp S, Koide R and Lynch J (1995). Exploitation of localized phosphorus-patches by common bean roots. Plant Soil. 1: 211-218.https://link.springer.com/article/10.1007/BF00010127.

Souza DMG and Lobato L (2006). Adubação fosfatada em solos da região do cerrado. Informações Agronômicas: Potafós. 10: 1-16. www.ipni.net/publication/ia-brasil.nsf/0/...\$FFILE/ENCARTE102.PDF.

Szareski VJ, Carvalho IR, Rosa TC, Dellagostin SM, et al. (2018). Oryza wild species: an alternative for rice breeding under abiotic stress conditions. Am. J. Plant Sci. 9: 1093-1104.

Szareski VJ, Carvalho IR, Kehl K, Levien AM, et al. (2017). Univariate, multivariate techniques and mixed models applied to the adaptability and stability of wheat in the Rio Grande do Sul State. Genet. Mol. Res. 16: gmr16039735. https://doi.org/10.4238/gmr16039735.

Tawaraya, K, Horie R, Saito S, Wagatsuma T, et al. (2014). Metabolite Profiling of Root Exudates of Common Bean under Phosphorus Deficiency. Metabolites. 4: 599-611. http://dx.doi.org/10.3390 / metabo4030599.

Turuko M and Mohammed A (2014). Effect of different phosphorus fertilizer rates on growth, dry matter yield and yield components of common bean (Phaseolus vulgaris L.). J. Agr. Res. 2: 88-92.

Valderrama M, Buzetti S, Benett CGS and Andreotti M (2009). Sources and doses of nitrogen and phosporus in no till common beans. Pesq. Agropec. Trop. 9: 191-196. www.scielo.br/scielo.php?script=sci_arttext\&pid=S010006832007000600031.

Zucareli C, Júnior EUR, Oliveira MA and Nakagava J (2010). Physiological and biometric indices in bean under different doses of phosphorus. Semina Ciênc Agrár. 3: 1313-1324. http://dx.doi.org/10.5433/16790359.2010v31n4Sup1p1313.

Zucarelli C, Prando AM, Júnior EUR and Nakagava J (2011). Fósforo na produtividade e qualidade de sementes de feijão Carioca Precoce cultivado no período das águas. Rev. Ciênc. Agron. 42: 32-38. http://ccarevista.ufc.br/seer/index.php/ccarevista/article/view/749.

Zucareli C, Júnior EUR and Oliveira MA (2012). Growth of Phaseolus vulgaris cv. IAC Carioca Tybatã due to phosphate fertilization. Rev. Ciênc. Agrovet. 1: 44-58. revista.udesc.br/index.php/agroveterinaria/article/view/5256. 